\title{
Divergent Approaches Regulating Beta Agonists and Cloning of Animals for Food: USA and European Union
}

\author{
Terence J. Centner \\ College of Agricultural and Life Sciences, The University of Georgia, Athens, \\ Georgia, USA \\ tcentner@uga.edu
}

Ludivine Petetin

Law School, Cardiff University, United Kingdom

\begin{abstract}
Technologies being used to produce nonhuman animals who are used for meat and dairy products are viewed by some people as meaningful. Two technologies receiving scrutiny in agriculture are beta agonists that are fed to food animals to improve weight gain and cloning animals to secure offspring with specific traits. The technologies enhance the productive capacities of animals so that fewer resources are needed to produce meat and dairy products. Yet consumers are not sure they want food products with beta agonist residues and that are produced from clones. In overseeing the safety of food products and animals, legislators and regulators in the United States (US) and European Union (EU) have developed contrasting provisions regarding the usage of these technologies. An evaluation of heuristics involving information and experiences with bovine spongiform encephalopathy and animal production technologies offers support in explaining the US's and EU's divergent provisions.
\end{abstract}

\section{Keywords}

animal welfare - beta agonists - cloning - food animals - heuristics - regulation 


\section{Introduction}

Many members of the public are concerned about what they eat and their exposure to injurious substances in food products they consume. In the United States (US), 3,000 people die per year and one in six people become sick from contaminated foods or beverages (US CDC, 2013). Some believe food products have been altered from their natural states in ways that are unhealthy due to the use of technological advances involving nonhuman animal feed additives, genetically engineered (GE) crops, hormones, irradiation, veterinary drugs, and cloned animals (Bové \& Dufour, 2001). Consumers wanting food items that are not associated with certain technologies are offering to pay more for such products. A market for specialized food products can be seen in thriving organic and locally-grown food markets.

This paper looks at governmental oversight of two technologies: beta agonists used as animal feed additives and cloning animals used for food. These two technologies are being employed by producers of animals used for food because they reduce the resources needed to produce meat and dairy products. With fewer resources required, producers may be more competitive and more land would be available to grow crops for human consumption. Simultaneously, the technologies are accompanied by concerns about food safety, animal welfare, and non-scientific factors.

Despite the evaluation of the same science involved with these technologies, the oversight by governments in the US and European Union (EU) has been different. The EU banned the use of beta agonists in the feed of animals used in food production in 1996 (EU, 1996), while the US approved their use in animal feed in the 2000s. With respect to cloning, a report by the EU in 2015 noted the importance of animal health and welfare in responding with restrictions on cloned products (European Commission, 2015). However, regulators in the US found no significant distinctions concerning animal welfare. The two technologies have gained approval for their use in the US but EU countries have thwarted their widespread adoption.

When addressing differences about the regulation of food products by the US and EU, the most common explanation is the application of the precautionary principle. This principle was adopted to apply to food law as part of an EU regulation adopted in 2002. Whenever "the possibility of harmful effects on health is identified but scientific uncertainty persists, provisional risk management measures necessary to ensure the high level of health protection chosen in the Community may be adopted" (European Parliament and the Council of the European Union, 2002). 
Some Americans maintain that the precautionary principle fails to incorporate "sound science," which should govern the acceptance of food products (US Congress, 2003). The inference of the American concern is that the precautionary principle is a disguised barrier to trade that allows a minority opinion to form the basis for precluding a product (Lupien, 2002).

This includes the use of the principle by the $\mathrm{EU}$ as a justification for banning meat products containing beta agonist residues (Lively, 2013). However, research on risks related to other technologies suggests that American regulations impose more precaution for many situations (Weiner et al., 2014). This supports a conclusion that precaution may not form the dividing line for the transatlantic discord between the US and EU on animal production practices involving inputs such as beta agonists and cloning.

The objective of this paper is to analyze why the US and EU approach the regulation of beta agonists and cloning differently. By looking at the availability of information and experiences with technologies already being used in animal production, justifications may be discerned for the conflicting interpretations of similar data. Affect and availability heuristics led decisionmakers in the US and EU to interpret the risks of beta agonists and cloning differently.

\section{Materials and Methods}

\section{Beta Agonist Feed Additives}

The technology of using of beta-adrenergic agonist drugs (beta agonists) as additives in livestock feed is accompanied by residues in meat products that may pose a risk to human health. The use of beta agonists has been approved in the United States and Canada, and the Codex Alimentarius has adopted international acceptable daily intake limits for these substances. Conversely, the European Union and most other countries feel the residues pose health risks. They have adopted provisions to exclude meat products containing residues of these drugs.

Ractopamine hydrochloride and zilpaterol hydrochloride are beta agonist drugs fed to selected animals used for food to enhance muscle growth, improve feed efficiency, and limit the amount of fat in meat products (Mersmann, 2002). Ractopamine was approved by the US Food and Drug Administration (US FDA) for use in swine in 2000 and cattle in 2003 (US FDA, 2000, 2003), and zilpaterol was approved by the US FDA for use in cattle in 2006 (US FDA, 2006). These drugs activate protein synthesis and decrease protein degradation on a cellular level in animals used for food to stimulate skeletal muscle growth 
without increasing natural hormone levels (Gonzalez et al., 2007). Thus, they cause protein accretion that increases the animals' hot carcass weight and improve yield grade with corresponding economic benefits for producers (Boyd et al., 2015). American livestock producers are feeding their animals beta agonists because of the economic advantages (Lean et al., 2014).

Yet many important meat-importing countries have claimed that there may be potential human health problems from beta agonists and have adopted policies to preclude the sale of products containing beta agonist residues (Bories et al., 2009). Beta agonist drug residues in food products are known to adversely affect humans, although there are no reported cases of humans being adversely affected by livestock products containing zilpaterol or ractopamine residues (Baynes et al., 2016).

Concern also exists about the welfare of animals (American Veterinary Medical Association, 2014; Loneragan et al., 2014). Evidence suggests that beta agonists lead to fatigued cattle syndrome that are manifested through labored breathing, reluctance to move, and lameness (Grandin, 2013; Thomson et al., 2015). In 2013, the drug firm Merck took its zilpaterol feed additive off the market due to its negative effects on animal health (Hughlett, 2013). Research on pigs suggests that those fed beta agonists exhibited more aggressive behaviors and a greater number of offensive behaviors, particularly bites (Poletto et al., 2010). These data provide justifications for determining that the usage of animals in the production of food is contrary to the acceptable norms.

\section{Cloning of Animals Used for Food}

The cloning of animals used for food involves food animals by using the somatic cell nucleus transfer (SCNT) cloning technique (Edwards et al., 2003). The main objectives of reproductive animal cloning for livestock are to increase reproductive efficiency, enhance animal genetic improvement, and to increase resistance to disease (Liu et al., 2016; US FDA, 2014, 2015). In agriculture, cloning generates animals for breeding. The offspring of clones are used for food production.

Agency risk assessments. The US FDA and the European Food Safety Authority (EFSA) reviewed similar scientific evidence of the SCNT cloning technique to determine whether animal cloning and its derived foods were safe (US Center for Veterinary Medicine, 2008; EFSA, 2008). Their 2008 risk assessments were science-based and focused on problems with genetic reprogramming, animal health risks, and food consumption risks. The agencies concluded that animal clones and their offspring are similar to their conventional counterparts, and that the safety of the meat and milk of clones and their progeny is similar compared with products from conventionally bred animals 
TABLE 1 Comparison of the evaluation of the cloning of nonhuman animals used for food in the US and EU

\begin{tabular}{|c|c|c|}
\hline & United States & European Union \\
\hline Evaluation setting & food risks & novel food \\
\hline Safety of cloned food products & yes & yes \\
\hline $\begin{array}{l}\text { Health of dams carrying clones } \\
\text { compared to other dams }\end{array}$ & comparable & inferior health \\
\hline $\begin{array}{l}\text { Welfare of cloned animals } \\
\text { compared to non-clones }\end{array}$ & comparable & inferior welfare \\
\hline $\begin{array}{l}\text { Products of offspring of cloned } \\
\text { animals }\end{array}$ & no differences & no differences \\
\hline Evaluation of ethical concerns & none occurred & $\begin{array}{l}\text { European Group on Ethics in } \\
\text { Science and New Technologies }\end{array}$ \\
\hline Public opposition to cloning & some & significant \\
\hline Establishing safeguards & $\begin{array}{l}\text { voluntary } \\
\text { moratorium }\end{array}$ & $\begin{array}{l}\text { developing special directives or } \\
\text { a regulation to preclude sale of } \\
\text { products }\end{array}$ \\
\hline
\end{tabular}

SOURCES: US CENTER FOR VETERINARY MEDICINE, 2008; EFSA, 2012; EUROPEAN COMMISSION, 2013B

(Petetin, 2009). However, a closer examination shows that the agencies reached different conclusions regarding the health of the animals (Table 1).

The US FDA noted a higher proportion of health risks for cloned animals but concluded that the risks did not qualitatively differ from those of natural breeding (US Center for Veterinary Medicine, 2008). Because the US FDA risk assessment found no science-based reason to require labels to distinguish between products from clones and products from conventionally produced animals, products from cloned animals are not labeled in the United States (US FDA, 2008).

The EFSA (2012) delineated issues of welfare and health of the surrogate dams carrying the cloned offspring. The dams were affected by abnormal pregnancies that included abortions. The agency also noted that the cloning efficiency of cattle, namely the percentage of viable offspring born from transferred embryo clones, is low at about 6 to $15 \%$ for bovine animals and about 6\% for pigs (EFSA, 2012; European Commission, 2013b). Moreover, the EFSA expressed concerns about animal suffering, as an increased percentage of clones have been found to be adversely affected, often severely and with a 
fatal outcome, compared to sexually produced animals (EFSA, 2008). This led the EFSA to conclude that the welfare of a significant proportion of clones was negatively impacted, leading the EU to take a protectionist approach to this technology (Petetin, 2012). With respect to the safety of food products from cloned animals, the EFSA did not make any risk management decision because its authority is limited to independent scientific evidence.

The policies and regulation of cloned foods. The approach of the US FDA to cloned foods was founded on the 1986 Coordinated Framework of Biotechnology (US Office of Science and Technology Policy, 1986). Because cloned food raised no unique risk, no new laws were needed to respond to challenges posed by this technology (US FDA, 2008). The US FDA declared that cloned foods are basically as safe as traditional foods, so they do not require any specific labeling information on cloning. However, the US FDA (2008) recommended that cloned species other than cows, goats, and pigs should not enter the human food supply.

The EU regulation of cloned foods falls under the scope of the 2015 Novel Foods Regulation (European Parliament and the Council of the European Union, 2015). Cloned foods are considered as novel foods and must be preauthorized. A novel food is labeled to inform consumers whenever it is no longer equivalent to an existing food (Petetin, 2017). Novel foods that give rise to ethical concerns may require additional specific labeling. The 2015 Novel Foods Regulation taking effect on January 1, 2018, simplifies the framework for novel foods (European Parliament and the Council of the European Union, 2015). The regulation creates a centralized authorization system for novel foods and establishes the EFSA at the center of the risk assessment. It applies to cloned foods until more specific legislation is enacted.

Foods derived from the descendants of cloned animals fall outside the scope of the definition of a novel food under the 2015 Novel Foods Regulation. This means that products of descendants of cloned animals are not subject to the pre-market authorization, labeling, or traceability requirements of these regulations. Since the descendants of clones will provide food products, consumers will not know whether their food was derived from a cloned animal unless new requirements are imposed.

Dissatisfaction with the existing regulations on cloned food led the EU Commission to submit two separate proposals dealing with animal-cloning and derived foods in 2013. The first proposal was for a Directive on Animal Cloning for Farming Purposes that would provisionally ban such practices (European Commission, 2013a). The second complementary proposal was for a Directive on Cloned Foods that would temporarily prohibit placing products on the market from clones as well as their importation (European Commission, 2013b). 


\section{Affect and Availability Heuristics}

Decisions about risk are influenced by affect and availability heuristics, the mental shortcuts people take when making judgments and choices. An affect heuristic involves a person's response to a risk based on experiences (Pachur et al., 2012). The availability heuristic looks at the information available to people making decisions (Mase et al., 2015).

Affect and availability heuristics may influence decisions made by the three groups of people who determine safeguards that will govern animal meat products. The first group of decisionmakers is composed of the scientists who determine what to examine, how the examination will proceed, and how to interpret the findings. While scientists are highly trained and seek to be objective in verifying scientific accounts of nature, science is messy (Lather, 2010). Scientists do not have a set of standardized questions or rules to follow; rather, they decide what questions should be asked (Haack, 2003). Scientists decide what experiments to conduct, so they make choices based on their knowledge and past experiences.

The second group of decisionmakers is comprised of legislators who enact provisions governing the use of technologies. They have choices in determining which scientific findings are the most credible, whether oversight is needed, and what limitations to establish. Opinions of constituents and advocacy groups, which may not be based on science, are often important (Miller, 2009). Once legislative pronouncements have been made, regulators are in charge of developing regulations to implement the legislation. They may evaluate the same science as the scientists but may make choices influenced by legislative directives, staffing, available expertise, and timeframes (US FDA, 2010).

When scientists, legislators, and regulators assess the risks of new technologies, such as beta agonists and cloned food products, their past experiences with related technologies may influence their evaluations of risk (Miller, 2009). The availability of information on related technologies and the regulation of these technologies may also impact their evaluations (EFSA, 2014). Given the uncertainties that accompany the assessment of risks, heuristics may lead individual decisionmakers to weigh the risks of new technologies dissimilarly and to ascribe divergent levels of precaution to accompanying risks (Stoutenborough et al., 2016). Due to their unique backgrounds and locations, individuals weigh risks of the same technology differently.

Cultural differences between the US and EU on food safety may have also influenced evaluations of risk. Europeans may have greater aversion to dread and unknown risk (Finucane et al., 2005). They also have been more supportive of actions to improve the welfare of animals used for food (Matheny \& Leahy, 2007). 


\section{Animal Production Technologies}

Heuristics related to other animal production technologies would be expected to influence decisionmakers. An examination of the agricultural law literature over the past two decades discloses several technologies for which the US and EU proceeded differently with their regulatory oversight. Based on the contrasting decisions concerning authorization to use these technologies, six are selected for further evaluation and assessment of how they may have influenced decisionmakers who evaluated risks accompanying the use of beta agonists and cloning. While decisionmakers on both sides of the Atlantic would have had access to considerable information about the technologies, they would have been exposed to different governmental and public attitudes about the technologies.

In approaching their evaluations of beta agonists and cloning, decisionmakers would be expected to maintain consistency with established cultural institutions and public sentiments. Legislators and regulators in the EU had already adopted regulations forbidding the use of steroidal hormones, recombinant bovine somatotropin (rBST), and some non-therapeutic antibiotics (European Commission, 1981, 1988; EU, 1996, 1998b), whereas in the US, the use of these production inputs was considered important to the viability of the country's livestock industry. Decisionmakers in both the US and EU would have had access to information on their existing regulatory controls over concentrations of animals, tail docking, and the castration of pigs without anesthesia.

The analysis of responses of US and EU regulators and producers to six animal production technologies shows a pattern (Table 2). Regulators in the US allowed the technologies to be adopted accompanied by measures to prevent harm. Considerable numbers of producers in the US embraced the technologies to maintain profitability and to enhance economic returns. However, EU regulators applied limitations and prohibitions. For those technologies allowed in the EU, producers were more reluctant to adopt them and expressed greater concern for animal welfare.

The use of steroidal hormones in the production of food animals is a technology that is regulated in the US and EU. The US Department of Agriculture commended the use of hormones in 1991 and, due to the economic advantages of adopting these agents, a significant number of US producers commenced using them. Steroidal hormones being used are estradiol benzoate, estradiol $17 \beta$, melengestrol acetate, progesterione, testosterone, trenbolone acetate, and zaranol (Schweihofer \& Buskirk, 2016). In contrast, the European Community adopted a directive to preclude the administration of steroidal hormones in 1981 that was amplified through additional directives (European Commission, 
TABLE 2 Prevalence of use of selected animal production technologies

Practice US EU Reference

Steroidal hormones

Recombinant bovine somatotropin

Non-therapeutic antibiotics

Concentrations of animals

Tail docking

Castration without anesthesia $+\quad$ - USDA, 2013; EC, 1981, 1988; EU, 1996

$+\quad$ - Wolf et al., 2011; Brinkman, 200o; EU, 1999

$+\quad$ - Sneeringer et al., 2015; EU, 1998

+ - US Government Accountability Office, 2008; European Parliament and the Council of the European Union, 2004

+ $\quad$ - Rault et al., 2011; EU, 2008

+ $\quad$ - Rault et al., 2011; EU, 2008

Notes. + = greater use; - = less use.

1981, 1988; EU, 1996). These provisions show a sustained antipathy to the use of steroidal hormones in food animal production in the EU.

The use of rBST in dairy cows is a second production technology. It is approved in the US but proscribed in the EU. In 1993, the US FDA approved the use of rBST in lactating dairy cows for the purpose of increasing the production of marketable milk (US FDA, 1993). Subsequently, this artificial hormone is available for use in the US in contrast with the EU where the use of rBST is banned (EU, 1999).

Another technology used for producing food animals on some farms involves the administration of non-therapeutic antibiotics. The US continues the use of these substances to enhance animal growth, although recent limitations should decrease usage (Centner, 2016; Sneeringer et al., 2015). This may be contrasted to the EU's 1998 regulation limiting the use of certain antibiotics in animal production (EU, 1998a).

Governmental limitations on the tail docking of pigs, including allowing the procedure without anesthesia, involve the use of a technology related to animal welfare. Tail docking is done to reduce biting by other pigs in confined areas (Larsen et al., 2015). Docking may have negative consequences for the welfare of the docked pig including acute pain and possibly long-term pain with the formation of neuromas in the tail stump (EFSA, 2007). Tail docking is prevalent in the US and is usually preformed a few days after birth without analgesia (Sutherland \& Tucker, 2011). In the EU, the tail docking of pigs is only allowed where there is evidence that injuries to other pigs' tails have occurred (EU, 2001; EU, 2008; European Commission, 2001). 
The castration of male pigs without anesthesia involves another technology related to animal welfare (EU, 2008). In both the US and EU, it is generally performed without anesthesia or post-operative analgesia even though the vocalization of animals suggests it is painful (Rault et al., 2011). However, an EU council directive requires castration of pigs older than seven days be performed by a veterinarian using an anesthetic agent (EU, 2008).

A major difference between the US and EU concerning the production of livestock is that large cattle feedlots and integrated pig and poultry operations are prevalent in the US (US Government Accountability Office, 2008). The assemblage of large numbers of animals at production units known as concentrated animal feeding operations (CAFOs) creates economies of scale. In the EU, while farms have increased in size, there has not been the same embracement of CAFOs as occurred in the US. Under the EU's Common Agricultural Policy, the EU chose to focus on protecting small-scale farming viability (Barnes et al., 2016). With direct payments to farmers and an emphasis on farm diversification and environmental maintenance, producers in the EU retained their holdings.

A majority of these six technologies have been available for public scrutiny for more than a decade. Decisionmakers in the US and EU would have had information on the public attitudes, practices by agricultural producers, activities by business firms, and agendas of special interest groups about these technologies. The prevalence of use of these technologies in the US and their limited use or prohibition in the EU mean that American and European decisionmakers had different information, experiences, and beliefs when called upon to regulate beta agonists and cloning.

Given the prohibitions on using steroidal hormones, rBST, and some nontherapeutic antibiotics in the EU, it was consistent for decisionmakers to assess the risks and apply precaution in a manner that led to reaffirming the EU ban on beta agonists and the possible ban of the cloning of food animals. Animal health concerns in the EU, expressed in regulations on tail docking and castration, supported a finding that the cloning of food animals had adverse effects on surrogate dams. Affect and availability heuristics caused EU decisionmakers to be concerned about the potential for meat products to contain unhealthy residues and failing to maintain the well-being of food animals that had been expressed in earlier regulations governing other technologies. In the US, decisionmakers observed public acceptance of meat products from animals administered steroidal hormones and antibiotics as well as the stressful conditions for animals confined at CAFOs. With these observations, US decisionmakers concluded that the use of beta agonists and cloning were simply two additional technologies that could be made available to producers to reduce the costs of animal production. 


\section{Results}

The use of beta agonists and cloning in food animal production show differences in opinion on what actions governments should take to address risks accompanying new technologies. Governments can choose not to act and allow new technologies to be unregulated, but legislative bodies in both the US and the EU have felt that beta agonists and cloning need to be regulated to protect animals, people, and the environment. However, the regulatory oversight in the US and EU has led to contrasting results. The evaluation of how scientists, legislators, and regulators assess risk and apply precaution helps explain the different conclusions on regulating these technologies. The decisionmakers in the US and EU viewed information differently given diverse regulatory institutions, market structure, interest groups, public attitudes, and politics. Concomitant with these various perspectives, decisionmakers would interpret data on beta agonists and cloning based on personal experiences, a perceived need to be consistent with regulations of other animal production technologies, and value judgments about the welfare of humans and animals used for food.

\section{Assessing Risk}

Risk plays a crucial role in the regulation of foods and is especially significant since scientific evidence is often inconclusive. Although scientific risk assessments may be perceived to be value-free, neutral, and unbiased (Haack, 2003), scientific inquiry incorporates notions of risk and conceptions of scientific evidence (Kang, 2013). Technologies include uncertainties, choices for perspectives, and value-loadings, so they are not comprised of stand-alone, factual answers (Saltelli \& Funtowicz, 2004). Rather, the evaluation of risk involves defining risks, analyzing inconclusive scientific evidence, making assumptions, assigning probabilities, and discerning acceptable levels of potential damages.

While the evaluation of risk accompanying beta agonists and cloning involves scientific evidence, legislative and regulatory decisions to protect people, animals, and the environment involve the values of the decisionmakers. For beta agonists, the EU's prohibition is to protect the health of people. The EFSA Panel on Additives and Products or Substances used in Animal Feed concluded that there was no human study from which to derive an acceptable daily intake for beta agonist residues (Bories et al., 2009). This precluded the calculation of tolerances (maximum residue limits) for meat products so any product with a residue is unacceptable. For cloning, the EU's decision was not based on human health concerns but rather considered the evidence that the technology adversely affected the welfare of animals. It was felt that surrogate dams and animal clones had too many health problems (European Group on Ethics in Science and New Technologies, 2008). 
In addressing beta agonists and cloning, the US FDA and the EFSA had nearly identical scientific data about the technologies, yet the agencies' assessments led to different policies. While the US decided to allow producers to use beta agonists and allows the cloning of food animals, the EU proscribed beta agonists and addresses cloning as a novel food. One explanation for the divergent assessment of risk is the heuristics affecting the decisionmakers. As a result of the decisionmakers' experiences with the six noted animal production technologies, affect and availability heuristics influenced their evaluations of risk and their decisions on how much precaution was needed to protect people, nonhuman animals, and the environment. These heuristics may account for the discrepancies in the US and EU regulations on beta agonists and cloning.

\section{Welfare of Animals Used for Food}

For cloning, the EU decisionmakers interpreted the data to conclude that the technology adversely affects surrogate dams and some offspring. By finding differences in the health of surrogate dams and cloned offspring, the decisionmakers in the EU acknowledged that animal welfare is important and could constitute a justification for not approving a new technology.

In 1998, the EU acknowledged concern for the welfare of animals produced for food with its adoption of a directive on the protection of animals kept for farming purposes (EU, 1998b). The 1998 directive provided the foundation for subsequent decisions to safeguard the welfare of animals used for food. In 1999, the Scientific Committee on Animal Health and Welfare concluded that rBST increases risks of clinical mastitis, the duration of the treatment of mastitis, and the incidence of foot and leg disorders; it also adversely affects reproduction and induces severe reactions at the injection site (EU, 1999). Based on these findings, the EU prohibited the use of rBST. The EU decisions on the tail docking and castration of pigs also were based on animal welfare concerns (EFSA, 2007; EU, 2001, 2008). Given these precedents regarding the treatment of animals used for food and the assessments of dams and offspring, the decisionmakers consider it "prudent to provisionally prohibit the use of cloning in animal production for farm purposes of certain species" (European Commission, 2013a).

In the US, common law traditionally treats nonhuman animals as property. Individual US states have enacted animal cruelty laws to prevent abusive behavior, but these often do not address most issues affecting the welfare of animals used for food. Moreover, they are not always enforced (Friedrich \& Wilson, 2015). In the absence of significant regulatory provisions protecting animal welfare in the US, decisionmakers declined to recognize any concerns about the health of surrogate dams used for cloning. 


\section{Discussion}

Citizens of the US and EU have a lot in common. Both the US and the EU have approached the issue of food safety with great diligence and have adopted a wide array of provisions to protect people from harmful substances and products. Both America and Europe are known for their safe food products. Yet, they have not approached all issues in the same manner. The evaluation of beta agonists and cloning shows that the US FDA and the EFSA have approached the risks involving these technologies differently.

For beta agonists, the US FDA has set acceptable daily intake levels and tolerance levels, whereas the EU has decided that residues are unacceptable due to human health concerns. For animal cloning, the US FDA found no distinctions in products from cloned animals, so no further regulation was needed, whereas the EU found the technology adversely affected animal health.

In applying the precautionary principle, the EU grants regulators discretion in regulating risk that can lead to products being banned (Morag-Levine, 2014). However, the US also applies precaution in regulating risk. A comprehensive study of the application of precaution by the US and EU showed that political and institutional factors, legal systems, and the role of cost-benefit analyses did not account for the observed patterns of precaution (Weiner et al., 2014). Rather, the authors concluded that heuristic availability provided more important clues about the use of the precautionary principle and cross-cultural differences in risk perception (Weiner et al., 2014).

Heuristic availability is access to information that will affect a person's memory (Geurten et al., 2015). By drawing on personal experiences and individual senses, the availability heuristic affects people's perceptions of risk and regulatory oversight (Mase et al., 2015). For beta agonists and cloning, people who evaluated the risks, applied precaution, and authored the regulations had experiences and information that may have impacted their perceptions of the regulatory needs of these technologies. Since both of these technologies dealt with animals used for food, decisionmakers may have been influenced by events and existing regulatory controls over six agricultural technologies related to animal well-being and wholesome food (Table 2).

For decisionmakers in the EU, the affect heuristic may include public and governmental responses to the potential introduction of GE crops and the use of ruminant-derived protein in animal feed. Public concerns over the introduction of GE crops contributed to a strengthened precautionary principle including its application to food items (European Parliament and the Council of the European Union, 2002). In 1985, ruminant-derived protein was related to an outbreak of bovine spongiform encephalopathy (BSE), also known as 
mad cow disease, in the United Kingdom (Burka, 2011). Ten years later, BSE was related to humans dying from Creutzfeldt-Jakob disease. This development caused the public to become more skeptical of governmental regulations (Jasanoff, 2005). In the United Kingdom, 176 human deaths were connected to the disease, with deaths peaking in 2000 (Andrews, 2012).

Given the seriousness of the Creutzfeldt-Jakob disease outbreak in the UK, decisionmakers in the EU were likely to have had an enhanced concern about health dangers that might accompany the use of new technologies. With this background, the regulatory climate of the EU was less favorable to the use of steroidal hormones, rBST, non-therapeutic antibiotics, concentrations of animals, tail docking, and castration without anesthesia. When the decisionmakers analyzed the data concerning potential health effects related to beta agonist residues in meat products, they wanted to avoid another adverse public health problem and so concluded that the usage of beta agonists was not safe for humans.

\section{Conclusion}

The regulatory agencies of the US and EU applied precaution in reaching their decisions on the use of beta agonists and cloning but delineated contrasting responses. While the application of the precautionary principle by the EU is offered as explaining the differences, an evaluation of affect and availability heuristics offers an alternative explanation. The decisionmakers evaluated risks differently. American decisionmakers had information and experiences showing widespread acceptance by regulators of new animal production technologies, including steroidal hormones, rBST, non-therapeutic antibiotics, and other production practices. While there was concern about animal health and welfare, it was not at the level expressed in EU directives.

However, European decisionmakers had very different information and experiences. Decisionmakers would have known about the existing EU prohibitions on steroidal hormones, rBST, and non-therapeutic antibiotics. Turning to the issue of animal welfare, EU decisionmakers were constrained by the directive to ensure animals are not caused unnecessary suffering (EU, 1998b). In regulating cloning, decisionmakers would want to be consistent with the animal welfare standards embodied in directives on tail docking and castration. Furthermore, due to the disease outbreak of BSE, EU decisionmakers may have had negative emotional reactions to new animal technologies. 
The analysis shows that decisionmakers in the US and EU adopted precaution in devising regulations over beta agonists and cloning. However, despite the internationalization of food safety standards, past experiences led decisionmakers in the US and EU to assess risk differently, caused the EU to have a greater concern about potential harm, and led the Americans to fail to find any adverse health concerns for animals receiving the technologies. While the EU's precautionary principle facilitates the rejection of technologies, the use of beta agonists and cloning was unacceptable because it would not be consistent with regulations governing other animal production technologies. Decisionmakers in the US and EU developed divergent regulatory approaches on the use of beta agonists and cloning technologies due to affect and availability heuristics.

\section{Acknowledgment}

The research presented here is based upon work that is supported by the National Institute of Food and Agriculture, U.S. Department of Agriculture, under award number GEOoo821.

\section{References}

American Veterinary Medical Association. (2014). Use of $\beta$-Adrenoreceptor Agonists (pp. 1-7). May 9, 2014, Washington, DC.

Andrews, N. J. (2012). Incidence of variant Creutzfeldt-Jakob disease diagnoses and deaths in the UK January 1994-December 2011. United Kingdom Creutzfeldt-Jakob Disease Research and Surveillance Unit, July 2, 2012.

Barnes, A., Sutherland, L.-A., Toma, L., Matthews, K., \& Thomson, S. (2016). The effect of the Common Agricultural Policy reforms on intentions towards food production: Evidence from livestock farmers. Land Use Policy 50, 548-558.

Baynes, R. E., Dedonder, K., Kissell, L., Mzyk, D., Marmulak, T., ... Riviere, J. E. (2016). Health concerns and management of select veterinary drug residues. Food and Chemical Toxicology 88, 112-122.

Bories, G., Brantom, P., Brufau de Barberà, J., Chesson, A., Cocconcelli, P. S., ... Wester, P. (2009). Safety evaluation of ractopamine: ESFA panel on additives and products or substances used in animal feed (FEEDAP). European Food Safety Authority Journal 1041, 1-52.

Bové, J., \& Defour, F. (2001). The world is not for sale. New York: Verso. 
Boyd, B. M., Shakelford, S. D., Hales, K. E., Brown-Brandl, T. M., Bremer, M. L., ... Erickson, G. E. (2015). Effects of shade and feeding zilpaterol hydrochloride to finishing steers on performance, carcass quality, heat stress, mobility, and body temperature. Journal of Animal Science 93, 5801-5811.

Budka, H. (2011). Editorial: The European response to BSE: A success story. European Food Safety Authority Journal 9(9), e991.

Centner, T. J. (2016). Recent government regulations in the United States seek to ensure the effectiveness of antibiotics by limiting their agricultural use. Environment International 94, 1-7.

Edwards, J. L., Schrick, F. N., McCracken, M. D., van Amstel, S. R., Hopkins, F. M., \& Davies, C. J. (2003). Cloning adult farm animals: A review of the possibilities and problems associated with somatic cell nuclear transfer. American Journal of Reproductive Immunology 50(2), 113-123.

EFSA (European Food Safety Authority). (2007). The risks associated with tail biting in pigs and possible means to reduce the need for tail docking considering the different housing and husbandry systems. European Food Safety Authority Journal 611, 1-13.

EFSA. (2008). Final scientific opinion on the food safety, animal health and welfare and environmental impact of animals derived from cloning by Somatic Cell Nucleus Transfer (SCNT) and their offspring and products obtained from those animals. European Food Safety Authority Journal 767, 1-49.

EFSA. (2012). Update on the state of play of animal health and welfare and environmental impact of animals derived from SCNT cloning and their offspring, and food safety of products obtained from those animals. European Food Safety Authority Journal 10(7), 2794, 1-42.

EFSA. (2014). Statement on a conceptual framework for the risk assessment of certain food additives re-evaluated under Commission Regulation (EU) No 257/2010. EFSA Panel on Food additives and Nutrient Sources added to Food. European Food Safety Authority Journal 12(6), 3697, 1-11.

EU. (1996). Council Directive 96/22/EC of 29 April 1996. O.J. (L 125) 3-8.

EU. (1998a). Council Directive 98/58/EC of 20 July 1998. O.J. (L221) 23-27.

EU. (1998b). Council Regulation No 2821/98 of 17 December 1998. O.J. (L 351) 4-8.

EU. (1999). Council Directive 1999/74/EC of 19July 1999. O.J. (L203) 53-57.

EU. (2001). Council Directive 2001/88/EC of 23 October 2001. O.J. (L 316) 1-12.

EU. (2008). Council Directive 2009/120/EC of 18 December 2008. O.J. (L 47) 5-13.

European Commission. (1981). Council Directive 81/602/EEC of 31 July 1981. O.J. (L 222) 32-33.

European Commission. (1988). Council Directive 88/146/EEC of 7 March 1988. O.J. (L 70) 16-18. 
European Commission. (2001). Commission Directive 2001/93/EC of 9 November 2001 amending Directive 91/630/EEC laying down minimum standards for the protection of pigs. O.J. (L 316) 36-38.

European Commission. (2013a). COM(2013)892 final. Proposal for a Directive of the European Parliament and of the Council on the cloning of animals of the bovine, porcine, ovine, caprine and equine species kept and reproduced for farming purposes. Retrieved from http://eur-lex.europa.eu/legal-content/EN/TXT/PDF/?uri=CELEX:5 2013PCo892\&from=EN.

European Commission. (2013b). COM(2013)893. Proposal for a Council Directive on the Placing on the Market of Food from Animal Clones. Retrieved from http://www.ipex .eu/IPEXL-WEB/dossier/document/COM20130893.do.

European Commission. (2015). Study on the labelling of products from cloned animals and their offspring. Brussels: Directorate-General for Agriculture and Rural Development.

European Parliament and the Council of the European Union. (2002). Regulation (EC) No 178/2002 of 28 January 2002. O.J. (L31) 1-24.

European Parliament and the Council of the European Union. (2015). Regulation $(E U)$ 2015/2283 of 25 November 2015. O.J. (L 327) 1-22.

Finucane, M. L., \& Holup, J. L. (2005). Psychosocial and cultural factors affecting the perceived risk of genetically modified food: An overview of the literature. Social Science \& Medicine 6o, 1603-1612.

Friedrich, B., \& Wilson, S. (2015). Coming home to roost: How the chicken industry hurts chickens, humans, and the environment. Animal Law 22, 103-164.

Geurten, M., Willems, S., Germain, S., \& Meulemans, T. (2015). Less is more: The availability heuristic in early childhood. British Journal of Developmental Psychology 33, 405-410.

Gonzalez, J. M., Carter, J. N., Johnson, D. D., Ouellette, S. E., \& Johnson, S. E. (2007). Effect of ractopamine-hydrochloride and trenbolone acetate on longissimus muscle fiber area, diameter, and satellite cell numbers in cull beef cows. Journal of Animal Science $85,1893-1901$.

Grandin, T. (2013). Zilpaterol riddle. Beef. November 2013, 30 \& 34.

Haack, S. (2003). Defending science-Within reason: Between scientism and cynicism. Amherst, NY: Prometheus Books.

Hughlett, M. (2013). Cattle feed additive is pulled from the market. Star Tribune (Minneapolis, MN), August 17, 2013, p. 1D.

Jasanoff, S. (2005). Design on nature. Princeton, NJ: Princeton University Press.

Kang, S. (2013). Irrationality and regulation: Constructing mad cow knowledge in the US-South Korea FTA. Globalizations 10(4), 587-601.

Larsen, M. L. V., Anderson, H. M.-L., \& Pedersen, L. J. (2015). Can tail damage outbreaks in the pig be predicted by behavioural change? Veterinary Journal 209, 50-56. 
Lather, P. (2010). Engaging science policy: From the side of the messy. New York: Peter Lang.

Lean, I. J., Thompson, J. M., \& Dunshea, F. R. (2014). A meta-analysis of zilpaterol and ractopamine effects on feedlot performance, carcass traits and shear strength of meat in cattle. PLOS ONE 9(12), 1-28.

Liu, X., Wang, Y., Tian, Y., Yu, Y., Gao, M., ... Zhang, Y. (2016). Generation of mastitis resistance in cows by targeting human lysozyme gene to b-casein locus using zinc-finger nucleases. Proceedings of the Royal Society B 281, 20133368.

Lively, T. (2013). Technical trade barriers facing U.S. meat exports. Choices 28(1), 1-3.

Loneragan, G. H., Thomson, D. U., \& Scott, H. M. (2014). Increased mortality in groups of cattle administered the b-adrenergic agonists ractopamine hydrochloride and zilpaterol hydrochloride. PLOS ONE 9(3), 1-13.

Lupien, J. R. (2002). The precautionary principle and other non-tariff barriers to free and fair international food trade. Critical Reviews in Food Science and Nutrition $42(4), 403-415$.

Mase, A. S., Cho, H., \& Prokopy, L. S. (2015). Enhancing the social amplification of risk framework (SARF) by exploring trust, the availability heuristic, and agricultural advisors' belief in climate change. Journal of Environmental Psychology 41, 166-176.

Matheny, G., \& Leahy, C. (2007). Farm-animal welfare, legislation, and trade. Law \& Contemporary Problems 70(1), 326-358.

Mersmann, H. J. (2002). Beta-adrenergic receptor modulation of adipocyte metabolism and growth. Journal of Animal Science 80, E24-E29.

Miller, K. C. (2009). The limitations of heuristics for political elites. Political Psychology 30(6), 863-894.

Morag-Levine, N. (2014). The history of precaution. American Journal of Comparative Law 62, 1095-1131.

Pachur, T., Hertwig, R., \& Steinmann, F. (2012). How do people judge risks: Availability heuristic, affect heuristic, or both? Journal of Experimental Psychology: Applied 18(3), 314-330.

Petetin, L. (2009). Clone Wars? The challenges of cloned food in EU, US and wTo Law. Environmental Law Review 11, 246-263.

Petetin, L. (2012). The revival of modern agricultural biotechnology by the UK government: What role for animal cloning? European Food \& Feed Law Review 6, 296-311.

Petetin, L. (2017). Precaution and equivalence-The critical interplay in EU biotech foods. European Law Review 42, 831-847.

Poletto, R., Meise, R. L., Richert, B. T., Cheng, H. W., \& Marchant-Forde, J. N. (2010). Behavior and peripheral amine concentrations in relation to ractopamine feeding, sex, and social rank of finishing pigs. Journal of Animal Science 88, 1184-1194.

Rault, J.-L., Lay, Jr., D. C., \& Marchant-Forde, J. N. (2011). Castration induced pain in pigs and other livestock. Applied Animal Behaviour Science 135, 214-225. 
Saltelli, A., \& Funtowicz, S. (2004). The precautionary principle: Implications for risk management strategies. International Journal of Occupational and Medical Environmental Health 17(1), 47-58.

Schweihofer, J. P., \& Buskirk, D. D. (2016). Farm to fork-Part 1 - Antibiotics and hormones. East Lansing, MI: Michigan State University Department of Animal Science. Retrieved from http://fec.msue.msu.edu/uploads/files/2016_FEC/Hormones_-_ Buskirk_-_FEC.pdf.

Sneeringer, S., MacDonald, J., Key, N., McBride, W., \& Mathews, K. (2015). Economics of antibiotic use in U.S. livestock production. US DA Economic Research Report No. 2000, November 2015 .

Stoutenborough, J. W., Vedlitz, A., \& Xing, X. (2016). Are all risk perceptions created equal? Comparing general risk assessments and specific risk assessments associated with climate change. Human and Ecological Risk Assessment: An International Journal 22(1), 50-70.

Strech, D., \& Tilburt, J. (2008). Value judgments in the analysis and synthesis of evidence. Journal of Clinical Epidemiology 61(6), 521-524.

Sutherland, M. A., \& Tucker, C. B. (2011). The long and short of it: A review of tail docking in farm animals. Applied Animal Behaviour Science 135, 179-191.

Thomson, D. U., Loneragan, G. H., Henningson, J. N., Ensley, S., \& Bawa, B. (2015). Description of a novel fatigue syndrome of finished feedlot cattle following transportation. Journal of the American Veterinary Medical Association 247(1), 66-72.

US CDC (Centers for Disease Control and Prevention). (2013). CDC and food safety. Atlanta, GA. Retrieved from http://www.cdc.gov/foodborneburden/PDFs/CDC -and-Food-Safety.pdf.

US CDC. (2014). Confirmed variant Creutzfeldt-Jakob Disease (variant CJD) case in Texas. Atlanta, GA, October 7, 2014. Retrieved from http://www.cdc.gov/prions/vcjd/news .html.

US Center for Veterinary Medicine. (2008). Animal cloning: A risk assessment. Rockville, MD.

US Congress. (2003). Expressing sense of the House supporting United States in its efforts in WTO to end European Union's trade practices regarding biotechnology. Congressional Record H5106-H5136, House of Representatives, June 10, 2003. Retrieved from https://www.congress.gov/crec/2003/06/10/CREC-2003-06-10.pdf.

US FDA (Food and Drug Administration). (1993). Animal drugs, feeds, and related products; sterile sometribove zinc suspension. Federal Register 58, 59946-59947.

US FDA. (2000). New animal drugs for use in animal feeds; ractopamine hydrochloride. Federal Register 65(17), 4111-4112.

US FDA. (2003). New animal drugs; ractopamine. Federal Register 68(181), 54658-5466o.

US FDA. (2006). New animal drugs; zilpaterol final rule. Federal Register 71(224), $53005-53006$. 
US FDA. (2008). Animal cloning and food safety. January 2008. Retrieved from https:// www.fda.gov/ForConsumers/ConsumerUpdates/ucm148768.htm.

US FDA. (2010). Task force on the utilization of science in regulatory decision making: Preliminary report and recommendations. August 2010.

US FDA. (2014). Animal cloning: Myths about cloning. Retrieved from http://www.fda .gov/AnimalVeterinary/SafetyHealth/AnimalCloning/ucmo55512.htm.

US FDA. (2015). Genetically engineered animals: General Q\&A. Retrieved from http://www.fda.gov/AnimalVeterinary/DevelopmentApprovalProcess/Genetic Engineering/GeneticallyEngineeredAnimals/ucmu13605.htm.

US Office of Science and Technology Policy. (1986). Coordinated framework for the regulation of biotechnology. Federal Register 51(26), 23302-23350.

Weiner, J., Rogers, M. D., Hammitt, J. K., \& Sand, P. H. (2014). The reality of precaution: Comparing risk regulation in the US and Europe. Washington, DC: Resources for the Future.

WHO and FAO. (2015). Evaluation of certain veterinary drug residues in food. WHO Technical Report Series 988, Seventy-eighth Report of the Joint FAo/wHo Expert Committee on Food Additives. Geneva. 